\title{
The Use Of PBL-Based Interactive Multimedia To Develop Student Science Process Skill
}

\author{
W. Fitriani ${ }^{1 *}$, Abdulah², A. Mustadi ${ }^{3}$ iD \\ 1,2,3 Department of Primary Education, State University of Yogyakarta, Yogyakarta, Indonesia \\ *Corresponding author: windi.fitriani@gmail.com
}

\begin{abstract}
Natural science was a lesson content that equipped and prepared students to have various essential skills for life; one of them is science process skill. However, natural science learning used for investing this skill was not run maximally, proven from the process and learning outcome. This research aimed to offer a solution related to that problem by developing Problem Based Learning-based interactive multimedia and effectiveness testing of PBL-based interactive multimedia to improve the science process skill. The research approach was research and development in which the research subjects consisted of students and teachers from cluster 01, Depok Sub-district, Sleman. The first field test obtained a score of 3.2, which was included in a mediate category, while the operational field test obtained a score of 4.3 , which was included in the very good category. The independent t-test obtained a significance of $0.001<0.05$, meaning that there was a significant difference between the experimental and control classes. This research was implied that the learning media and model could influence the achievement of the student. Therefore, the selection should be well considered according to the learning characteristics and students.
\end{abstract}

Keywords: Interactive Multimedia, PBL, Science Process Skill

$\begin{array}{lll}\text { History: } & \text { Publisher: Undiksha Press } \\ \text { Received } & : 6 \text { January } 2021 & \text { Licensed: This work is licensed under } \\ \text { Revised } & : 11 \text { February } 2021 & \text { Creative Commons Attribution 3.0 License } \\ \text { Accepted }: \text { 26 March } 2021 & \text { Pablished : } 25 \text { April } 2021 & \end{array}$

\section{Introduction}

Science in a global education system is more than just a fact-based science. Science education is meaningless and cannot be understood by the students when they cannot relate science to their life (Hartley, Plucker, \& Long, 2016; Jessani, 2015). On the other hand, the changes in many fields have brought many complex problems that must be solved soon. Hence, science education in Indonesia, or people calling it natural science (IPA), should equip the students with science and useful skills for their future lives. One of the essential skills to be mastered and embedded through natural science education is science process skills (Darmaji et al., 2019; Nugroho, 2018). Through this process skill, the students are trained to face situations structurally bypassing these following stages to identify the problem based on the science or knowledge owned, make a hypothesis, determine relevant variables, make experimental design, and conclude (Germann, 1991; Özgelen, 2012).

Moreover, learning with process skills can make students more active than reading the book merely. This result is in line with the research done by Yoo \& MacDonald (2014) that learning with process skills can improve learning outcomes and student skills like problemsolving, collaboration, leadership, and management ability. However, the science process skill cannot appear immediately, but it undergoes continuous training and exercises. This 
statement is in line with the research done by Farsakoglu, Sahin, \& Karsli (2012) that the process skill is built through experience, and the individual develops their skills through exercise. Hence, to make the student ability mastering science process skill maximally, the learning process must be designed well to support the goal achievement.

Although science process skill is an important skill to be mastered, the science process skill is still the biggest problem of science education nowadays (Hodosyová, Útla, MonikaVanyová, Vnuková, \& Lapitková, 2015). This situation also happens in Indonesia, which is indicated by the result of PISA in 2018. The result showed that Indonesian students were positioned in 72 of 77 countries for the category of science (Odell, Gierl, \& Cutumisu, 2021; Pratiwi, 2019). However, the low ability illustrated that the learning process does not run as it should be. This statement is proven from the field through observation and interview in SD Negeri cluster 01, Depok Sub-district, Yogyakarta. The learning is still centered on the teacher, while the students have more memorizing activities than discovering their science or knowledge. Besides, the learning is only referred to as the student book and teacher book, and a minimum of media utilization.

Although, natural science is a lesson content that concerns the daily phenomenon that is often difficult only to be explained through words or writing. On the other hand, the school can create better learning due to the facility availability as a laptop and LCD projector, which can be used by the teacher every time. However, the facility is not benefitted maximally because of the limit of teacher capability to utilize technology-based media. Regarding those facts, the improvement of natural science learning can be made by benefitting the potential owned by the school, in the form of learning media supporting facilities. This result is in line with the research done by Primamukti \& Farozin (2018) that the attempt to improve learning quality is one strategy that can be exerted through learning media. There are several kinds of learning media, start from conventional media until digital-based media like multimedia. Multimedia is used more effectively than conventional media because it can contain and display information in pictures, video, writing, or audio.

Furthermore, according to Islam, Ahmed, Islam, \& Shamsuddin (2014), through text, graphic, audio, animation displays, multimedia technology can create a high-quality learning environment for students. Lindner, Eitel, Barenthien, \& Köller (2018) have shown that multimedia in learning can improve the student cognitively, either during learning or testing situations. Adigüzel \& Orhan (2017) have argued that multimedia has characteristics of a picture, audio, video integrity, and other communicative features that can produce various learning environments and develop the student role in the learning process. Based on that outcome, the multimedia is appropriate to use in natural science learning, regarding that the learning content of natural science is not enough to only be explained in words, but also needs to be visualized more clearly, thus, it will not cause misconception on the students.

Besides the proper media selection, the quality of learning is also affected by the learning model. Each lesson content has different characteristics; then, the model used cannot be equalized. For example, natural science is a lesson content closely related to daily problems since natural science learns about things in the real world. On the other hand, the learning model close to daily life, which provides adaptation and integration opportunities in surrounding students, is problem-based learning (PBL) (Gorghiu, Drăghicescu, Cristea, Petrescu, \& Gorghiu, 2015). The model of problem-based learning (PBL) emphasizes problem-solving, which is taken from real-life surround the students, then, through those problems, the students will feel challenged to explore, so they can find a solution to solve the problems.

Compared to traditional learning, which puts the student in the position of knowledge consumer, they only have a superficial learning effect and will be used in direct teaching. PBL is more appropriate to natural science learning. This was because problem-based 
learning offers an effective procedure for the students, so it can help to build their basic skills in various domains (Gorghiu et al., 2015). Handika \& Wangid (2013), in the study of problem-based learning, the students are always demanded to seek information, so this learning step can help the students develop science process skills. The research done by Wardani (2017) has resulted that problem-based learning will significantly affect the science process skill of 5 th class students than the learning with direct instruction. The other research done by Liu, Liu, Pan, Zou, \& Li (2019) on the students of 5-10 years old has shown that students involved in problem-based learning (PBL) will use their knowledge and science behavior be improved significantly. Therefore, based on problem-based learning (PBL) is expected to support the success of natural science learning.

Based on the explanation of problems, previous research findings, and relevant theory, improving the science process skill through problem-based learning base interactive multimedia is recommended. Multimedia is a learning media that aims to ease the message or lesson delivery to the students, and on the other hand, the science process skill is developed through a problem-based learning model. Therefore, through the proper media selection and appropriate learning model use, it is expected to maximize the learning process. Therefore, this study aims to develop the interactive multimedia of problem-based learning (PBL) to improve the science process skill and tested multimedia.

\section{Materials and Methods}

This research exerted a research and development (R\&D) approach with 9 research steps. The research steps consisted of research and information collection, planning, first product development, first field test, main product revision, main field test, operational product revision, operational field test, and last product revision (Borg \& Gall, 1983).

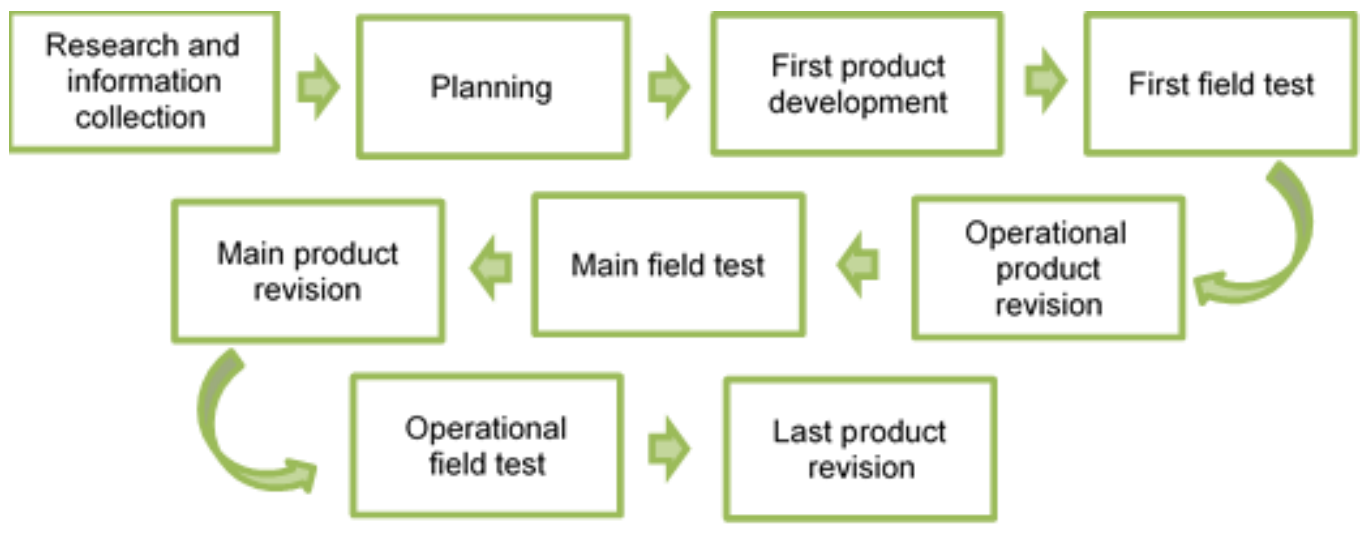

Figure 1. The Steps of Research Development

The research time was done for two months, from November - December. This research was done in cluster 01, Depok Sub-district, Sleman, Yogyakarta which covered to SD Negeri Karangwuni, SD Negeri Caturtunggal 01, and SD Negeri Caturtunggal 03. The research subject consisted of need analysis subject of 5th class teacher in cluster 01, first field test subject of seven 5th class students of SD Negeri Karangwuni, main field test subject of 25 5th class students of SD Negeri Caturtunggal 01, operational field test subject of SD Negeri Caturtunggal 03 as the experiment class as many as 20 students and SD Negeri Caturtunggal 01 as the control class as many as 20 students.

The validity of multimedia was valued by using a validation sheet by the media expert and subject expert. During the first file and operational field testing, the students were given a 
response questionnaire to respond to the developed multimedia. The score achievements were then converted into 5 scales qualitative data based on the formula (Widoyoko, 2009).

Table 1. The Conversion of 5 Scales Qualitative Data

\begin{tabular}{lcc}
\hline \multicolumn{1}{c}{ Formula } & Score Conversion & Category \\
\hline $\mathrm{X}>\mathrm{Xi}+1.8$ isd & $>4.2$ & Very Good \\
$\mathrm{Xi}+0.6$ isd $<\mathrm{X} \leq \mathrm{Xi}+1.8$ isd & $>3.4-4.2$ & Good \\
$\mathrm{Xi}-0.6$ isd $<\mathrm{X} \leq \mathrm{Xi}+0.6$ isd & $>2.6-3.4$ & Adequate \\
$\mathrm{Xi}-1.8$ isd $<\mathrm{X} \leq \mathrm{Xi}-0.6$ isd & $>1.8-2.6$ & Less \\
$\mathrm{X} \leq \mathrm{Xi}+1.8$ isd & $\leq 1.8$ & Very Less \\
\hline
\end{tabular}

The effectiveness of multimedia use was valued by exerting pretest and post-test questions. Therefore, the design was referred to as pretest and post-test control group design (Creswell, 2014).

Table 2. Pretest and Posttest Control Group Design

\begin{tabular}{lccc}
\hline \multicolumn{1}{c}{ Group } & Pretest & Treatment & Posttest \\
\hline Experiment & O1 & $\mathrm{X}$ & O3 \\
Control & O2 & - & O4 \\
\hline
\end{tabular}

The testing on science process skill was employed by giving essay test, as (Hodgson, Varsavsky, \& Matthews, 2014) have argued that generally the valuation of student process skill can be valued by giving essay test and a multiple-choice test. The given question was referred to on indicators of science process skill (Zeidan \& Jayosi, 2015) presented in Table 3.

Table 3. Indicator of Science Process Skill

\begin{tabular}{ll}
\hline \multicolumn{1}{c}{ Indicator } & \multicolumn{1}{c}{ Description } \\
\hline Observation & To focus on the nature of object and situation by using five senses \\
To measure & To reveal the total of particular object quantitatively \\
To conclude & To explain a particular object or substance quantitatively \\
To classify & $\begin{array}{l}\text { To relate the object and phenomenon according to nature or } \\
\text { characteristic } \\
\text { To predict }\end{array}$ \\
To communicate & $\begin{array}{l}\text { To use word, symbol or graphic to figure out the object, action, or } \\
\text { phenomenon }\end{array}$ \\
\hline
\end{tabular}

To determine whether it resulted in a significant difference between control and experiment class in the context of science process skill, it needed to do an independent t-test, firstly by doing normality tests. Further, the data analysis of multimedia use effectiveness in this research was calculated in the SPSS $26^{\text {th }}$ version.

\section{Results and Discussion Results}

The research finding concerned with multimedia development consisted of student response results to the multimedia, normality test result, and independent t-test. After validation by the expert, the multimedia will be tested in the field. There were three times of operational field tests. During the first and main field test, the students would be shown 
multimedia and given a response questionnaire to respond to the multimedia. Meanwhile, during the operational test, the experiment was required to identify the effectiveness of multimedia use. The students would be divided into two classes, as control class and experiment class, each consisting of 20 students. The students in the control class were treated by giving learning through video media and the usual learning model used by the teacher, while the students in the experiment class were treated by giving interactive multimedia that integrated into the problem-based learning (PBL) model. In each class, the students will be given pretest and post-test questions in essay tests due to the indicator of science process skill. After having pretest and post-test, the data were analyzed using an independent t-test to know the significant difference of science process skill between the control and experiment classes. Before having the independent t-test, it continued to the prerequisite test through the normality test.

Table 4. The Result of Student Response to Multimedia Use on the First Field Test

\begin{tabular}{lcc}
\hline \multicolumn{1}{c}{ Valuation Component } & Average Score & Score Conversion \\
\hline Learning & 22.8 & 3.3 \\
Display & 23.8 & 3.4 \\
Programming & 21.25 & 3 \\
Average & 23 & 3.2 \\
\hline
\end{tabular}

Table 5. The Result of Student Response to Multimedia Use on the Main Field Test

\begin{tabular}{lcc}
\hline \multicolumn{1}{c}{ Valuation Component } & Average Score & Score Conversion \\
\hline Learning & 125.7 & 4.5 \\
Display & 114.8 & 4.4 \\
Programming & 117 & 4.1 \\
Average & 119.1 & 4.3 \\
\hline
\end{tabular}

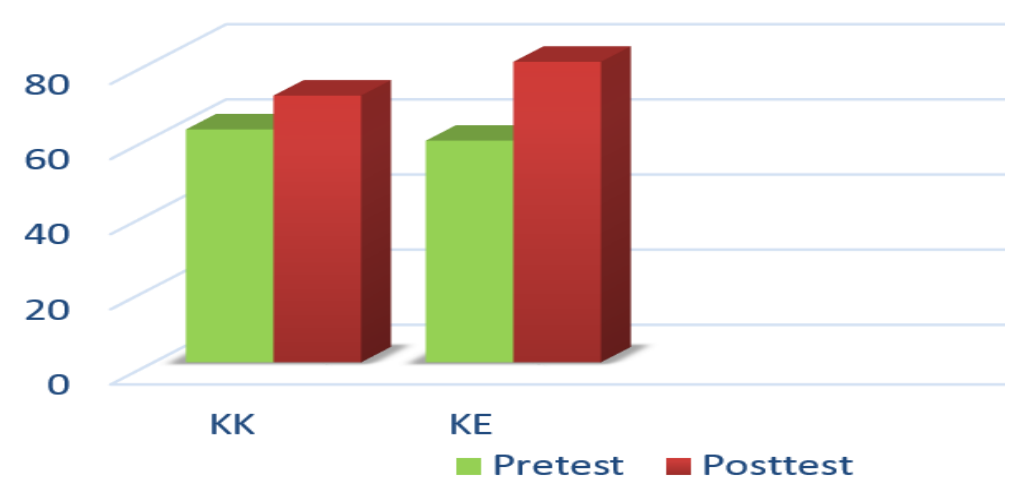

Figure 2. The Result of Science Process Skill Pretest-Posttest

Table 6. The Result of Normality Test of Science Process Skill Pretest-Posttest

\begin{tabular}{ccccc}
\hline Data & Class & Sig. (2-tailed) & Condition & Significance Explanation \\
\hline \multirow{2}{*}{ Pretest } & KK & 0.202 & \multirow{2}{*}{ P $>0.05$} & Normal \\
& KE & 0.187 & & \multirow{2}{*}{ Normal } \\
\hline
\end{tabular}


Tabel 7. The Result of Independent t-test

\begin{tabular}{ccccc}
\hline & Class & Sig. & Condition & Significance Explanation \\
\hline $\begin{array}{c}\text { Posttest } \\
\text { Data }\end{array}$ & $\begin{array}{c}\text { Control Class \& } \\
\text { Experiment Class }\end{array}$ & 0.001 & $\mathrm{P}<0.05$ & Significant \\
\hline
\end{tabular}

\section{Discussion}

The PBL-based interactive multimedia developed in the research was based on the problems that are occurred in cluster 01 specifically and problems of the education sector generally, due to the current condition that the world faces challenges of the 21 st Century that were different from the previous Century. Andini, Hidayat, \& Fadillah (2018) have asserted that society was demanded to generate quality human resources, who were able to face problems and global challenges. Therefore, it did not only need to the competence of science, but also competencies of skill, attitude, and value (Tirri, Cho, Ahn, \& Campbell, 2017). The essential skills that must be developed were science process skill, considering that science was a base for developing science and technology (Hidayah \& Pujiastuti, 2016). The science process skill could be embedded in students through problem-based learning that required the students to be actively seeking solutions to solve problems. The problems here were referred to daily problems closely related to the student's life, so the students could be easier to connect between science and problem. The development of PBL-based interactive multimedia was developed through several stages. Besides, the developed multimedia got validation from the experts and responses from the students.

Interpretation of Research Table

After validated by the expert, the next step was the first field test on the 5th class students of SD Negeri Karangwuni as many as 7 students. The first field test presented in table 4 showed that the developed multimedia could obtain an average score of 23 and be converted by using qualitative data with a scale of 5 , which has been developed by Widoyoko (2009). The score conversion showed 3.2, which was included in the adequate category. From several aspects of the response request, an aspect got a good response, as on the display aspect, while the aspects of learning and programming got enough response. The next step was product revision which was based on the first field test.

The main field test was done on students of the $5^{\text {th }}$ class of SD Negeri 03 Caturtunggal as many as 24 students. The result of student response on multimedia could obtain a score of 4.3 , which was included in the very good category. Next, the operational test was exerted to value media effectiveness. On the operational test, the students were given a pretest and a post-test in the essay task. The questions were focused on the questions which referred to the indicator of process skill. Figure 2 shows that the post-test from the experiment class was higher than the control class. During the pretest, the average score of the control class was 62 , while the experiment class was 59.

Nevertheless, during the post-test, the average score of the experiment class was higher; it was about 80, while the control class was 72 . The result of independent t-test showed a significant difference between the control class and experiment class. The result of the research was in line with the research finding by Primamukti \& Farozin (2018) under the title Utilization of Interactive Multimedia to Improve Learning Interest and Learning Achievement of Child, that the use of multimedia in learning was proved to be able to improve learning interest and outcome of 5th class students of SD Wonosari cluster 01, Gunungkidul District. The existence of a problem-based learning model that supports the achievement of science process skills also supports the findings of Alberida, Lufri, \& Barlian (2019) that problem-solving learning can improve students' process skills. 


\section{PBL-Based Multimedia in Natural Science Learning}

This research found a significant difference between the control class and experiment class on this research which was caused by several factors, as the difference of treatment given on the experiment class and control class. In the control class, the traditional learning model by using video media was implemented by the teacher. Meanwhile, in the experiment class, the learning was implemented in PBL-based interactive multimedia. Then, in the experiment class, the media was integrated into the learning model that fitted competence achievement. The use of multimedia was more effective to use in the learning process than video media. Mayer (2009) has said that multimedia contained instructional messages can encourage and support learning. The multimedia could provide a format in both word and image to display the instructional messages to readers. The word was formed in utterance and written text, while the image was formed in the silent picture as photo and moving image as animation and video. Thus, the multimedia could provide information from more than one ways of delivery. Wei, He, \& Huang (2018), the instructional multimedia provided individual instruction, which was concerned with students' ability to achieve educational purposes according to their skill and improve inadequate student learning, and replaced formal teaching methods. Therefore, the use of interactive multimedia could accommodate various student characteristics in the class. Moreover, Mayer (2009) has added that humans have two information systems: verbal and visual. When we got information visually only, the verbal potential would not benefit, or vice versa.

The use of multimedia could facilitate the students to obtain information through two systems of process at once. By displaying both of them simultaneously (verbal and visual information), it was the same way to display the subject twice, then the students could understand more information. Besides, the difference between video and multimedia was also on the level of interactivity. The interactive multimedia could have interactivity that was not owned by the video. The students could find the navigation button in multimedia, which enabled the students to set their learning speed. The students could also back or toward the subject frame. According to Surjono (2017), this interactive principle helps to support the optimality of student learning since the students could control and organize the speed of the subject display. Primamukti \& Farozin (2018) have found that the use of media in a learning process was able to help the teacher to build student comprehension so that student comprehension could be more profound. The media could also attract the students' interest to be more focused on their learning. Besides attracting the student interest, interactive multimedia could make the students more motivated than when they used conventional media. This result was in line with the research finding by Omenge \& Priscah (2016), which referred that multimedia in a learning process could make students more positive, encourage self-motivation, and show idea factors associated with support relevance and credibility increase comprehension. Through multimedia use, the natural science subject could be presented more authentic to the students. Wei et al. (2018) have argued that multimedia could display various subjects without limited space and time. The students could also build science and knowledge through communication, discussion, and interaction. Hence, learning could deliver good quality and achieve learning achievement.

Furthermore, the model of problem-based learning (PBL) integrated into multimedia also played a role in improving the student science process skill. Joham \& Clarke (2012) have found an approach that can fulfill the need for skill development from various groups of learning through a problem-based learning model. Within the problem-based learning, the students were given a problem that required them to look for a solution. The problem would be displayed in more real through multimedia, and then the teacher would explain the rules during the learning process. On the next step, the students recalled their knowledge which was related to a particular problem. Next, on problem-solving, the students would analyze 
several choices of the solution and select the most appropriate solution. The solution was obtained from activities that connected the problem with the science or knowledge owned by the students. The last step was a question and answer or communication session; in this part, the students did not only discuss substances that they have learned and how those substances could be helpful in particular situations, but they also discussed problem-solving. Ulger (2018) allowed students to construct their science and knowledge through the PBL model. The research finding by Koh, Khoo, Wong, \& Koh (2008) has found that the problem-based learning model could positively affect student learning and stimulate them to be whole lifelearners. Therefore, the student learning with the PBL model was more centered on the students, which affected the students to be more active, while the teacher was a facilitator.

This research was implied on media selection as supporting learning success and learning model selection according to subject content characteristics and objectives. The learning media could affect student learning outcomes since the media was able to help simplify the teacher to deliver the learning message. Moreover, multimedia was an effective media, regarding its use, which was able to help deliver information in many ways (audio and visual). The multimedia also provided easiness for the users since the navigation could be organized due to the need. In selecting multimedia as the learning media, it was better to consider several things: learning content, media ability to create learning effectiveness, and media suitability to student characteristics. If the media were fit to the student characteristics, it would ease them to involve within learning activities. Then, this media use could improve the student learning outcome. Natural science was a learning content closely related to the daily activities that needed this problem-based learning (PBL) model. Problem-based learning (PBL) could present real problems that the students must solve to train their skills during the problem-solving process. Thus, to achieve learning success, the teacher should choose the right learning media and model that fit the subject content and student characteristics.

\section{Conclusion}

This research finding showed that the problem-based learning (PBL) interactive multimedia, which has been developed through several steps, was feasible to use in the classroom. The result of student response on the main field test obtained a very good category. The PBL interactive multimedia use test referred that the result was significant, which indicated the difference within science process skill on control class and experiment class. This result was because the use of multimedia could facilitate the students to acquire information through two processing systems at once, so the students could understand more about the information. Besides, the problem-based learning model accommodated learning that connected learning in class and real life. The students could learn the real problems through process and steps, which it could develop their process skill.

\section{References}

Adigüzel, A., \& Orhan, A. (2017). The Relation Between English Learning Students' Levels of Self-Regulation and Metacognitive Skills and Their English Academic Achievements. Journal of Education and Practice, 8(9), 115-125. Retrieved from https://eric.ed.gov/?id=EJ1138845.

Alberida, H., Lufri, F., \& Barlian, E. (2019). Enhancing student's science process skills through problem solving model: An effectiveness study. Journal of Physics: Conference Series, 1317(1). https://doi.org/10.1088/1742-6596/1317/1/012181.

Andini, T. E., Hidayat, S., \& Fadillah, E. N. (2018). Scientific process skills: Preliminary study towards senior high school student in Palembang. Jurnal Pendidikan Biologi Indonesia, 4(3), 243-250. https://doi.org/10.22219/jpbi.v4i3.6784. 
Borg, W. R., \& Gall, M. D. (1983). Educational Research an Introduction. Longman.

Creswell, W. J. (2014). Research Design: qualitatative, quantitative, and mixed method approach. SAGE Publications.

Darmaji, Kurniawan, D. A., Astalini, Kurniawan, W., Anwar, K., \& Lumbantoruan, A. (2019). Students' Perceptions of Electronic's Module in Physics Practicum. 13(2), 288-294. https://doi.org/10.11591/edulearn.v13i2.13005.

Farsakoglu, Ö. F., Sahin, Ç., \& Karsli, F. (2012). Comparing science process skills of prospective science teachers: A cross-sectional study. Asia-Pacific Forum on Science Learning and Teaching, 13(1), 1-21. Retrieved from https://www.academia.edu/download/39385399/karsli_asia_pasific_2012.pdf.

Germann, P. J. (1991). Developing Science Process Skills through Directed Inquiry. The American Biology Teacher, 53(4), 243-247. https://doi.org/10.2307/4449277.

Gorghiu, G., Drăghicescu, L. M., Cristea, S., Petrescu, A.-M., \& Gorghiu, L. M. (2015). Problem-based Learning - An Efficient Learning Strategy in the Science Lessons Context. Procedia - Social and Behavioral Sciences, 191, 1865-1870. https://doi.org/10.1016/j.sbspro.2015.04.570.

Handika, I., \& Wangid, M. N. (2013). Pengaruh Pembelajaran Berbasis Masalah Terhadap Penguasaan Konsep Dan Keterampilan Proses Sains Siswa Kelas V. Jurnal Prima Edukasia, 1(1), 85. https://doi.org/10.21831/jpe.v1i1.2320.

Hartley, K. A., Plucker, J. A., \& Long, H. (2016). Creative self-efficacy and teacher ratings of student creativity in Chinese elementary classrooms. Thinking Skills and Creativity, 22, 142-151. https://doi.org/10.1016/j.tsc.2016.10.001.

Hidayah, R., \& Pujiastuti, P. (2016). Pengaruh PBL Terhadap Keterampilan Proses Sains Dan Hasil Belajar Kognitif IPA Pada Siswa SD. Jurnal Prima Edukasia, 4(2), 186. https://doi.org/10.21831/jpe.v4i2.7789.

Hodgson, Y., Varsavsky, C., \& Matthews, K. E. (2014). Assessment and teaching of science skills: whole of programme perceptions of graduating students. Assessment and Evaluation in Higher Education, 39(5), 515-530. https://doi.org/10.1080/02602938.2013.842539.

Hodosyová, M., Útla, J., MonikaVanyová, Vnuková, P., \& Lapitková, V. (2015). The Development of Science Process Skills in Physics Education. Procedia - Social and Behavioral Sciences, 186, 982-989. https://doi.org/10.1016/j.sbspro.2015.04.184.

Islam, B., Ahmed, A., Islam, K., \& Shamsuddin, A. K. (2014). Child Education Through Animation: An Experimental Study. International Journal of Computer Graphics \& Animation, 4(4), 43-52. https://doi.org/10.5121/ijcga.2014.4404.

Jessani, S. I. (2015). Science Education: Issues, Approaches and Challenges. Journal of $\begin{array}{llll}\text { Education and Educational Development, } & 79 .\end{array}$ https://doi.org/10.22555/joeed.v2i1.51.

Joham, C., \& Clarke, M. (2012). Teaching critical management skills: the role of problembased learning. Teaching in Higher Education, 17(1), 75-88. https://doi.org/10.1080/13562517.2011.590975.

Koh, G. C. H., Khoo, H. E., Wong, M. L., \& Koh, D. (2008). The effects of problem-based learning during medical school on physician competency: A systematic review. Cmaj, 176(1), 34-41. https://doi.org/10.1503/cmaj.070565.

Lindner, M. A., Eitel, A., Barenthien, J., \& Köller, O. (2018). An integrative study on learning and testing with multimedia: Effects on students' performance and metacognition. Learning and Instruction, 2018(1). https://doi.org/10.1016/j.learninstruc.2018.01.002. 
Liu, M., Liu, S., Pan, Z., Zou, W., \& Li, C. (2019). Examining science learning and attitude by at-risk students after they used a multimedia-enriched problem-based learning environment. Interdisciplinary Journal of Problem-Based Learning, 13(1), 6. https://doi.org/10.7771/1541-5015.1752.

Mayer, R. E. (2009). Multimedia Learning (Second). Cambridge University Press.

Nugroho, T. A. T. (2018). Pengembangan Multimedia Pembelajaran Interaktif Berbasis Mobile untuk Meningkatkan Kemampuan Berpikir Kritis dan Keterampilan Proses Siswa Kelas IV. Universitas Negeri Yogyakarta.

Odell, B., Gierl, M., \& Cutumisu, M. (2021). Testing measurement invariance of PISA 2015 mathematics, science, and ICT scales using the alignment method. Studies in Educational Evaluation, 68. https://doi.org/10.1016/j.stueduc.2020.100965.

Omenge, O. R., \& Priscah, M. J. (2016). Understanding the Utilization of Instructional Media in Training Health Professionals. IOSR Journal of Nursing and Healt Science (IOSRJNHS), 5(3), 1-8. https://doi.org/10.9790/1959-0503030108.

Özgelen, S. (2012). Students' science process skills within a cognitive domain framework. Eurasia Journal of Mathematics, Science and Technology Education, 8(4), 283-292. https://doi.org/10.12973/eurasia.2012.846a.

Pratiwi, I. (2019). Efek Program Pisa Terhadap Kurikulum Di Indonesia. Jurnal Pendidikan Dan Kebudayaan, 4(1), 51-71. https://doi.org/10.24832/jpnk.V4i1.115.

Primamukti, A. D., \& Farozin, M. (2018). Utilization of interactive multimedia to improve learning interest and learning achievement of child. Jurnal Prima Edukasia, 6(2), 111-117. https://doi.org/10.21831/jpe.v6i2.19183.

Surjono, H. D. (2017). Multimedia Pembelajaran Interaktif (1st ed.). UNY Press.

Tirri, K., Cho, S., Ahn, D., \& Campbell, J. R. (2017). Education for Creativity and Talent Development in the 21st Century. Education Research International, 2017, 1-2. https://doi.org/10.1155/2017/5417087.

Ulger, K. (2018). The effect of problem-based learning on the creative thinking and critical thinking disposition of students in visual arts education. Interdisciplinary Journal of Problem-Based Learning, 12(1), 10. https://doi.org/10.7771/1541-5015.1649.

Wardani, P. S. (2017). The Effect of Problem Based Learning Instruction on Students Science Process Skills in Physics. 5th SEA-DR (South East Asia Development Research) International Conference 2017 (SEADRIC 2017), 131-136. https://doi.org/10.2991/seadric-17.2017.28.

Wei, P. C., He, F., \& Huang, S. (2018). Effects of instructional multimedia integrated situational approach on students' learning achievement. Eurasia Journal of Mathematics, Science and Technology Education, 14(7), 3321-3327. https://doi.org/10.29333/ejmste/91244.

Widoyoko, E. (2009). Evaluasi Prograam Pembelajaran Panduan Praktis bagi Pendidik dan Calon Pendidik. Pustaka Pelajar.

Yoo, J. J., \& MacDonald, N. M. (2014). Developing 21st century process skills through project design. Journal of Family \& Consumer Sciences. Journal of Family \& Consumer Sciences, 106(3), 22-27. https://doi.org/https://www.ingentaconnect.com/content/aafcs/jfcs/2014/00000106/00 000003/art00006.

Zeidan, A. H., \& Jayosi, M. R. (2015). Science Process Skills and Attitudes toward Science among Palestinian Secondary School Students. World Journal of Education, 5(1), 1324. https://doi.org/10.5430/wje.v5n1p13. 